\title{
Performance of dairy cows fed normal- or reduced-starch diets supplemented with an exogenous enzyme preparation
}

\author{
T. Silvestre, ${ }^{1}$ M. Fetter, ${ }^{1}$ S. E. Räisänen, ${ }^{1}$ C. F. A. Lage,${ }^{2}$ H. Stefenoni, ${ }^{1}$ A. Melgar,,${ }^{1,3}$ S. F. Cueva, ${ }^{1}$ D. E. Wasson, ${ }^{1}$ \\ L. F. Martins, ${ }^{1}$ T. P. Karnezos, ${ }^{4}$ and A. N. Hristov ${ }^{1 *}$ \\ ${ }^{1}$ Department of Animal Science, The Pennsylvania State University, University Park 16802 \\ ${ }^{2}$ Veterinary Medicine Teaching and Research Center, School of Veterinary Medicine, University of California, Davis 93274 \\ ${ }^{3}$ Instituto de Innovation Agropecuaria de Panama, 161 Carlos Lara Street, Clayton, City of Knowledge, 07144, Panama \\ ${ }^{4}$ Purina Animal Nutrition, Arden Hills, MN 55126
}

\section{ABSTRACT}

The objective of this study was to investigate the effects of supplementation of an exogenous enzyme preparation (EEP) on performance, total-tract digestibility of nutrients, plasma AA profile, and milk fatty acids composition in lactating dairy cows fed a reduced-starch diet compared with a normal-starch diet (i.e., positive control). Forty-eight Holstein cows (28 primiparous and 20 multiparous) were enrolled in a 10-wk randomized complete block design experiment with 16 cows per treatment. Treatments were as follows: (1) normal-starch diet (control) containing (\% dry matter basis) $24.8 \%$ starch and $33.0 \%$ neutral detergent fiber (NDF), (2) reduced-starch diet (RSD) containing $18.4 \%$ starch and $39.1 \%$ NDF, or (3) RSD supplemented with $10 \mathrm{~g} / \mathrm{cow}$ per day of an EEP (ENZ). The EEP contained amylolytic and fibrolytic activities and was top-dressed on the total mixed ration at the time of feeding. Compared with normal-starch diet, dry matter intake and milk and energy-corrected milk (ECM) yields were lower (on average by 7.1, 9.5, and $7.2 \%$, respectively) for cows on the RSD treatments. Concentrations, but not yields, of milk fat and total solids were increased by RSD. Energy-corrected milk feed efficiency did not differ among treatments. Totaltract digestibility of NDF tended to increase by RSD treatments. Plasma AA concentrations were not affected by treatment, except that of 3-methylhistidine was increased by ENZ, compared with RSD. Blood glucose concentration tended to be lower in cows on the RSD treatments, but ENZ increased glucose and tended to increase insulin concentrations at $4 \mathrm{~h}$ after feeding when compared with RSD. Cows on the RSD treatments had decreased concentrations of de novo fatty acids and tended to have increased concentrations of preformed

Received September 9, 2021.

Accepted November 25, 2021.

*Corresponding author: anh13@psu.edu fatty acids in milk. Overall, decreasing dietary starch concentration by $26 \%$ decreased dry matter intake, milk, and ECM yields, but ECM feed efficiency was not different among treatments. The negative effects of reducing dietary starch on production were not attenuated by the EEP.

Key words: dietary starch, exogenous enzyme, dairy cow, wheat straw

\section{INTRODUCTION}

The energy requirements of lactating dairy cows in the United States were established from experiments conducted in the 1970s (Moe et al., 1972; NRC, 2001). They are calculated based on animal characteristics such as BW, milk production, and stage of lactation (Weiss and Pinos-Rodriguez, 2009). To meet the $\mathrm{NE}_{\mathrm{L}}$ requirements of a cow, several dietary interventions may be chosen by nutritionists, including provision of starch and digestible fiber in the diet (Oba and Allen, 1999). However, increasing the amount of fiber in the ration of dairy cows is limited by the inverse relationship between energy density and fiber content. For instance, higher proportion of dietary fiber can reduce feed intake (Allen, 1996), and the composition and physical characteristics of the fiber can influence the performance and ruminal parameters of cows (Dado and Allen, 1995). Decreased fiber inclusion in the diet, on the other hand, can result in digestive disturbances, ranging from altered ruminal fermentation pattern to severe acidosis (Mertens, 1997). The NRC (2001) reported that the ratio of forage to concentrate feeds in lactating dairy cow diets can affect DMI, and the mechanisms behind this effect are related to the amount and digestibility of forage fiber. In general, gut fill limits DMI at higher NDF concentrations, whereas energy demands regulate intake at lower NDF concentrations (Mertens, 1994).

As corn prices trend higher and are projected to continue to rise (USDA-ERS, 2021), investigating reducedstarch diets for dairy cattle is warranted (Gencoglu 
et al., 2010; Dann et al., 2015). Results from previous studies that partially replaced corn grain with forage or nonforage fiber sources reported similar FCM yields and minor changes in feed efficiency when dietary starch concentration was reduced by 15 to $20 \%$ (Weiss et al., 2011; Dann et al., 2015). In the Dann et al. (2015) study, however, a 18\% decrease in dietary starch concentration tended to decrease DMI and decreased milk production of the cows. In addition, increasing fiber content in the diet can negatively affect ammonia uptake by the rumen microbes and, consequently, the efficiency of milk protein synthesis in lactating cows (Hristov et al., 2005).

Research has suggested that supplementing dairy cow diets with exogenous enzymes preparations (EEP) could be a nutritional strategy to increase fiber digestibility while maximizing feed efficiency when lowquality forage or decreased-starch diets are fed (Arriola et al., 2011). Suggested modes of action of EEP include provision of readily fermentable substrates for ruminal microbes (McAllister et al., 2001), thus enhancing fiber, starch, and protein degradation in the rumen (Meale et al., 2014). In a meta-analysis evaluating EEP supplementation, Arriola et al. (2017) reported statistical trends for improved total-tract fiber digestibility and lactational performance of dairy cows, even though a large variability and inconsistency of responses are present in the literature. Evaluation of EEP becomes more difficult because of the wide range of products with different composition, activity, and doses applied (Meale et al., 2014). Furthermore, the enzymatic effects may depend on interactions of EEP with the type of forage fed (Yang et al., 2019). It is not clear if EEP supplementation of a reduced-starch diet would be enough to attenuate the deficiency of rumen-available energy by enhancing fiber degradability, and thus resulting in increased performance of dairy cows.

Therefore, the objective of this study was to investigate the effects of an Aspergillus spp.-based EEP on lactational performance, total-tract digestibility of nutrients, plasma AA profile and metabolites, and milk fatty acids (FA) composition in mid-lactation dairy cows fed a reduced-starch diet compared with a normal-starch diet (i.e., positive control). We hypothesized that supplementation of EEP would benefit ruminal fermentation by enhancing structural carbohydrate degradation, thereby increasing rumen energy availability and improving cow productivity.

\section{MATERIALS AND METHODS}

All procedures involving animals carried out in the study were approved by The Pennsylvania State University's Animal Care and Use Committee.

\section{Animals, Experimental Design, and Treatments}

The experiment was conducted in the freestall barn of The Pennsylvania State University's Dairy Teaching and Research Center. Forty-eight Holstein cows (28 primiparous and 20 multiparous) averaging ( \pm SD) $151 \pm 45 \mathrm{DIM}$ and $593 \pm 55 \mathrm{~kg}$ of $\mathrm{BW}$ at the beginning of the study were used in a randomized complete block design experiment. The experiment consisted of a 2 -wk covariate period followed by an 8 -wk experimental period, with the first 2 wk for adaptation to treatments and the last $6 \mathrm{wk}$ for data and sample collection. Cows were blocked based on parity, DIM, and milk yield (MY) during the covariate period, and cows within a block were randomly assigned to 1 of 3 treatments as follows: (1) normal-starch, positive control diet (NSD), (2) reduced-starch, negative control diet (RSD), and (3) RSD supplemented with $10 \mathrm{~g} / \mathrm{cow}$ per day of an exogenous enzyme extract from Aspergillus oryzae and Aspergillus niger (CelluloGest, Purina Animal Nutrition; ENZ). According to the manufacturer specifications, the ENZ product contained the following activities: amylase $\left(1.2 \times 10^{6}\right.$ modified Wohlgemuth units $/ \mathrm{kg})$, hemicellulase $(1.9 \times$ $10^{5}$ hemicellulase units $\left./ \mathrm{kg}\right)$, cellulase $\left(1.1 \times 10^{4}\right.$ cel- $^{-}$ lulase units $/ \mathrm{kg})$, glucanase $\left(1.0 \times 10^{3}\right.$ glucanase units/ $\mathrm{kg})$, and pectinase $\left(1.0 \times 10^{3}\right.$ pectinase units $\left./ \mathrm{kg}\right)$. Dose of ENZ followed the manufacturer's recommendations, and it was weighed individually to be top-dressed on the TMR daily during feeding. The EEP product was in a solid form and was mixed with approximately 500 $\mathrm{g}$ of the TMR after top-dressing. Based on visual observations by the research team, cows consumed the mixture of product and TMR immediately after they were fed. Based on the production data collected during the covariate period, the experimental diets were formulated to meet or exceed the $\mathrm{NE}_{\mathrm{L}}$ and $\mathrm{MP}$ requirements (NRC, 2001) of a lactating Holstein cow with $611 \mathrm{~kg}$ of BW, $32.7 \mathrm{~kg} / \mathrm{d}$ of MY, $4.00 \%$ milk fat, and $3.10 \%$ milk true protein at $23 \mathrm{~kg} / \mathrm{d}$ of DMI. In the RSD, ground corn grain was replaced by straw (Table 1). The NSD was offered to all cows during the covariate period. Straw was processed with a Standard Roto Grind hammer mill, model 760 (Roto Grind Tub and Grain Grinders, Burrows Enterprises, LLC), equipped with 6 sets of hammers with 18 standard hammers and 6 surfaced lead hammers. Theoretical particle size of the processed straw was set to $2.5 \mathrm{~cm}$. Cows were fed once daily at around $0800 \mathrm{~h}$, and feed was offered ad libitum targeting 5 to $10 \%$ refusals. Cows were milked twice daily at 0600 and $1800 \mathrm{~h}$ and always had free access to drinking water sources. Individual DMI was monitored with a Calan Broadbent Feeding System (American Calan Inc.). 
Table 1. Ingredients and chemical composition of the diets fed during the experiment

\begin{tabular}{|c|c|c|}
\hline \multirow[b]{2}{*}{ Item } & \multicolumn{2}{|c|}{$\operatorname{Diet}^{1}$} \\
\hline & NSD & $\begin{array}{c}\text { RSD } \\
\text { and ENZ }\end{array}$ \\
\hline \multicolumn{3}{|c|}{ Ingredient, $\%$ of $\mathrm{DM}$ or as indicated } \\
\hline Corn silage $^{2}$ & 44.4 & 44.4 \\
\hline Alfalfa haylage $^{3}$ & 13.1 & 13.1 \\
\hline Wheat straw $^{4}$ & 2.52 & 11.1 \\
\hline Whole roasted soybeans ${ }^{5}$ & 7.56 & 7.56 \\
\hline Whole cottonseed $^{6}$ & 4.09 & 4.09 \\
\hline Corn grain, ground ${ }^{7}$ & 8.59 & - \\
\hline Canola meal $^{9}$ & 9.9 & 9.9 \\
\hline SoyPLUS ${ }^{9}$ & 3.51 & 3.51 \\
\hline Molasses $^{10}$ & 4.55 & 4.55 \\
\hline Mineral and vitamin premix ${ }^{11}$ & 1.83 & 1.83 \\
\hline \multicolumn{3}{|l|}{ Composition, \% of DM } \\
\hline $\mathrm{CP}^{12}$ & 16.3 & 15.9 \\
\hline $\mathrm{RDP}^{13}$ & 9.5 & 9.3 \\
\hline RUP $^{13}$ & 7.2 & 7.0 \\
\hline $\mathrm{NDF}^{12}$ & 33.1 & 39.1 \\
\hline $\mathrm{ADF}^{12}$ & 20.4 & 25.1 \\
\hline $\operatorname{Starch}^{12}$ & 24.8 & 18.4 \\
\hline Ether extract ${ }^{13}$ & 4.9 & 4.7 \\
\hline $\mathrm{NE}_{\mathrm{L}}{ }^{13} \mathrm{Mcal} / \mathrm{kg}$ of $\mathrm{DM}$ & 1.60 & 1.57 \\
\hline $\mathrm{NE}_{\mathrm{L}}$ balance, ${ }^{13} \mathrm{Mcal} / \mathrm{d}$ & 2.80 & 1.40 \\
\hline MP balance, ${ }^{13} \mathrm{~g} / \mathrm{d}$ & -85 & -96 \\
\hline $\mathrm{NFC}^{13}$ & 34.6 & 29.1 \\
\hline $\mathrm{Ash}^{12}$ & 5.05 & 5.25 \\
\hline $\mathrm{Ca}^{12}$ & 1.01 & 1.03 \\
\hline $\mathrm{P}^{12}$ & 0.42 & 0.41 \\
\hline
\end{tabular}

${ }^{1} \mathrm{NSD}=$ control; $\mathrm{RSD}=$ reduced-starch; $\mathrm{ENZ}=\mathrm{RSD}$ supplemented with Aspergillus spp. exogenous enzyme product.

${ }^{2}$ Corn silage was $53.0 \% \mathrm{DM}$ and contained (DM basis) $8.3 \% \mathrm{CP}, 36.6 \%$ $\mathrm{NDF}, 22.6 \% \mathrm{ADF}$, and $39.5 \%$ starch.

${ }^{3}$ Alfalfa haylage was $41.8 \% \mathrm{DM}$ and contained (DM basis) $18.0 \% \mathrm{CP}$, $54.7 \% \mathrm{NDF}, 29.8 \% \mathrm{ADF}$, and $0.7 \%$ starch.

${ }^{4}$ Wheat straw contained (DM basis) $3.6 \%$ CP, $80.1 \%$ NDF, $58.1 \%$ $\mathrm{ADF}$, and $0.8 \%$ starch and was chopped with a Standard Roto Grind hammer mill, model 760 (Roto Grind Tub and Grain Grinders), equipped with 6 sets of hammers with 18 standard hammers and 6 surfaced lead hammers.

${ }^{5}$ Whole roasted soybeans contained $37.0 \% \mathrm{CP}$ (DM basis).

${ }^{6}$ Whole cottonseed contained $23.7 \% \mathrm{CP}$ (DM basis).

${ }^{7}$ Corn grain contained $8.3 \% \mathrm{CP}$ (DM basis). Corn grain was ground using a hammer mill (Case IH model 1250) through a 500- $\mu$ m screen. ${ }^{8}$ Canola meal contained $41.0 \%$ CP (DM basis).

${ }^{9}$ SoyPLUS (Landus Cooperative) contained 39.0\% CP (DM basis).

${ }^{10}$ Molasses was from Westway Feed Products.

${ }^{11}$ The premix (Cargill Animal Nutrition, Cargill Inc.) contained (\%, as-is basis) the following: trace mineral mix, $0.86 ; \mathrm{MgO}(56 \% \mathrm{Mg}), 8.0$; $\mathrm{NaCl}, 6.4$; vitamin ADE premix (Cargill Animal Nutrition, Cargill Inc.), 0.48; limestone, 37.2; selenium premix (Cargill Animal Nutrition, Cargill Inc.), 0.07; and dry corn distillers grains with solubles, 46.7; $\mathrm{Ca}, 14.1 \%$; P, 0.39\%; Mg, 4.59\%; K, 0.44\%; S, 0.39\%; Se, $6.91 \mathrm{mg} / \mathrm{kg}$; $\mathrm{Cu}, 362 \mathrm{mg} / \mathrm{kg} ; \mathrm{Zn}, 1,085 \mathrm{mg} / \mathrm{kg} ; \mathrm{Fe}, 186 \mathrm{mg} / \mathrm{kg}$; vitamin A, 276,717 $\mathrm{IU} / \mathrm{kg}$; vitamin D, 75,000 IU/kg; and vitamin E, 1,983 IU/kg.

${ }^{12}$ Values calculated using the nutrient analysis of the individual feed ingredients (Cumberland Valley Analytical Services Inc.) and their inclusion in the diets.

${ }^{13}$ Estimated based on NRC (2001) using averaged DMI, milk yield, milk composition, and BW of the cows during the experiment.

\section{Sample Collection}

Feed and TMR Sampling. Weights of feed offered and refusals were recorded daily. Fresh TMR, refusals, and feed ingredient samples were collected twice weekly and stored frozen at $-20^{\circ} \mathrm{C}$ until oven-dried at $55^{\circ} \mathrm{C}$ for $72 \mathrm{~h}$ for further analyses. Dried samples were ground using a Wiley mill (Thomas Scientific) through a 1-mm screen and composited by experimental week (TMR and forage samples) or for the entire experiment (concentrate feeds). Individual feed ingredients were analyzed at Cumberland Valley Analytical Services (Waynesboro, PA) by wet chemistry methods for CP (method 990.03; AOAC International, 2000), amylase-treated NDF (Van Soest et al., 1991), ADF (method 973.18; AOAC International, 2000), ether extract (method 2003.05; AOAC International, 2006), ash (method 942.05; AOAC International, 2000), minerals (method 985.01; AOAC International, 2000), and estimated NFC (NRC, 2001). Composite TMR samples were analyzed for starch according to Hall (2009) and indigestible NDF (iNDF) as described in Huhtanen et al. (1994) and as modified by Lee et al. (2012). Briefly, composited TMR samples (collected twice weekly) were dried at $55^{\circ} \mathrm{C}$, ground through a $1-\mathrm{mm}$ screen, weighted $(0.5 \mathrm{~g})$ into a $25-\mu \mathrm{m}$ pore size filter bag (Ankom Technology Corp.), and incubated for $12 \mathrm{~d}$ in the rumen of a rumen-cannulated cow. Six filter bags were incubated per treatment (i.e., NDS, RSD, and ENZ). Nutrient composition of the diets was reconstituted from analyzed values of individual feed ingredients and their inclusion rate in the TMR (Table 1).

Production Data Collection and Milk Sampling. Milk yield (Afimilk system) and BW (AfiFarm 3.04E scale system; S.A.E. Afikim, Rehovot) of the cows were recorded throughout the experiment. Body condition score was evaluated (NRC, 2001) during the second week of the covariate period and experimental wk 8 by a single trained person. Milk samples were collected during the second week of the covariate period and every other week during the experiment (excluding the adaptation period) from 2 consecutive p.m. and a.m. milkings (i.e., a total of 4 samples per week) into 20-mL tubes containing bromo-2-nitropropane-1,3-diol. Samples were analyzed for milk fat, true protein, MUN, lactose, and total solids concentrations, and SCC by Dairy One laboratory using Milkoscan models 6000, FT+, or 7 and Fossomatic models 5000 or FC (Foss Electric A/S). Separate unpreserved samples were also collected as described above and stored frozen at $-20^{\circ} \mathrm{C}$. These samples were composited per cow and period (i.e., covariate and experimental, wk 3-8) and analyzed for FA profile as described in Rico and Harvatine (2013). 
Fecal Sampling. During experimental wk 8, fecal samples were collected from each cow for estimation of total-tract digestibility of dietary nutrients. To obtain a representative sample of a 24 -h feeding cycle, spot fecal samples (approximately $500 \mathrm{~g}$ per cow and per sampling) were collected 4 times over $2 \mathrm{~d}$, at 0,4 , 8, and $12 \mathrm{~h}$ after feeding (i.e., 0800 and $1200 \mathrm{~h}$ on $\mathrm{d}$ 1 , and 1600 and $2000 \mathrm{~h}$ on $\mathrm{d} 2$ ). Fecal samples were obtained by rectal stimulation and dried at $55^{\circ} \mathrm{C}$ to constant weight. The dried samples were ground using a Wiley mill through a 1-mm sieve and composited by cow. Composited fecal samples were analyzed for $\mathrm{CP}(\mathrm{N} \times 6.25)$ using a Costech ECS 4010 elemental analyzer (Costech Analytical Technologies Inc.), ash, iNDF, ADF, and NDF with Ankom 200 fiber analyzer (Ankom technology Corp.) and starch (Hall, 2009) to determine total-tract $\mathrm{OM}, \mathrm{CP}, \mathrm{NDF}, \mathrm{ADF}$, and starch digestibility. Indigestible NDF was used as a total-tract digestibility marker (Schneider and Flatt, 1975). Composited fecal samples collected on wk 8 were processed and analyzed for iNDF as described for the TMR samples above.

Blood Sampling. Blood samples were collected from the coccygeal vein or artery during experimental wk 8 at $0,4,8$, and $12 \mathrm{~h}$ after feeding. Blood was collected into vacutainer tubes containing EDTA (Becton, Dickson and Company), placed on ice, and then the plasma was separated by centrifugation at 1,500 $\times g$ at $4^{\circ} \mathrm{C}$ for 15 min within 30 min of collection. Plasma samples were stored at $-20^{\circ} \mathrm{C}$ and composited by cow (on an equal volume basis). Composite samples of the 4 time points were analyzed for AA profile at the University of Missouri-Columbia's Agricultural Experiment Station Chemical Laboratory following the procedures of Deyl et al. (1986) and Fekkes (1996). Composite plasma samples were also analyzed for BHB (Autokit 3-HB Microliter Procedure; Wako Diagnostics), total FA (HR Series; Wako Diagnostics), BUN, and glucose (Idexx Laboratories Inc.). Insulin was analyzed using an ELISA kit (Bovine Insulin ELISA, Kit No. 10-1201-01, Mercodia AB). Plasma collected at $4 \mathrm{~h}$ after feeding was also analyzed for glucose. The inter-and intra-assay coefficients of variation for the insulin test were both $<10 \%$.

\section{Statistical Analysis}

One cow on the NSD treatment left the study during the first experimental week due to a toxemia caused by mycotoxins, and its data were not used for statistical analysis. All remaining data were analyzed using SAS (release 9.4, SAS Institute Inc.). Data were tested for normality using the UNIVARIATE procedure and processed for outliers based on the absolute studentized residue value $>3$ using the REG procedure. Data that were not normally distributed (i.e., SCC) were logtransformed for the statistical analysis. Statistical analysis of all data was performed using PROC MIXED. Cow was the experimental unit. Production data (DMI, MY, BW, and feed efficiency) were averaged per experimental week, and the averaged weekly data were used for the statistical analysis. Data collected during the 2-wk adaptation period were not included in the statistical analysis; wk 3 data (i.e., Figure 1) represented the first experimental week. Milk composition data were weighted averages based on the MY of the morning and evening milkings. Milk composition, DMI, and MY during each experimental week were used to calculate component yields, ECM, and ECM feed efficiency. The model for the production data contained treatment, week, the interaction treatment $\times$ week as fixed effects, and a covariate measurement; most treatment $\times$ week interactions were nonsignificant $(P>$ $0.05)$ and were removed from the final model. Where treatment $\times$ week interaction was significant, means separation was done using the PDIFF procedure of SAS. Data were analyzed as repeated measures with week as the repeated term using the $\operatorname{AR}(1)$ covariance structure. Nutrient intake and total-tract digestibility, plasma AA and metabolites, milk FA, BCS, and BW change data were analyzed with treatment as the only fixed effect. Block and block $\times$ treatment effects were included in all models as random effects. Orthogonal contrasts were used to evaluate the effect of replacing ground corn grain by wheat straw (i.e., NSD vs. RSD and ENZ) and the effect of ENZ (i.e., RSD vs. ENZ). Statistical differences were considered at $P \leq 0.05$, and tendencies were declared at $0.05<P \leq 0.10$. Data are presented as LSM or covariate-adjusted LSM (production data).

\section{RESULTS AND DISCUSSION}

\section{Production Data}

Feeding cows with RSD and ENZ decreased $(P \leq$ $0.03) \mathrm{MY}$ and ECM compared with NSD (Table 2). There was a treatment $\times$ week interaction $(P<0.001)$ for DMI, where cows fed the NSD had greater $(P=$ 0.03) DMI throughout the experiment, except during wk 3 and 5 (Figure 1). Examination of the raw DMI data did not indicate any reason for this discrepancy, and the interaction was considered an aberration. There was also a treatment $x$ week interaction for feed efficiency $(P<0.001)$, which was caused by the differential effect of treatment on DMI during wk 5 . For similar reasons, there was a treatment $\times$ week interaction $(P=0.006)$ for ECM feed efficiency. Milk fat, 
milk solids, and MUN concentrations were increased $(P \leq 0.04)$ by the reduced-starch diets, compared with NSD. The reduced-starch diets decreased $(P<0.001)$ milk lactose concentration and milk true protein, total solids, and lactose yields. There was a treatment $x$ week interaction for lactose and MUN concentrations $(P \leq 0.04)$. Examination of the data showed that lactose concentration was consistently greater $(P \leq 0.06)$ for NSD than the reduced-starch diets, except during wk $3(P \geq 0.30)$, which caused the interaction. In the case of MUN, the interaction was caused by a lack of effect of treatment $(P \geq 0.53)$ during wk 6 , whereas MUN concentration was greater $(P \leq 0.001)$ for the reduced-starch diets compared with NSD during all other experimental weeks. Cows fed the reduced-starch diets had lower $(P=0.02)$ average $\mathrm{BW}$ and gained less weight $(P=0.01)$ than cows fed NSD; however, diet did not affect BCS or BCS change during the experiment.

In the present study, ground corn grain was replaced by wheat straw in the reduced-starch diets to allow us to test the hypothesis that ENZ would increase diet (straw) NDF digestibility and enhance nutrient availability for microbial fermentation in the rumen, thus partially or totally compensating for the lower starch content of RSD compared with NSD. Although some studies have demonstrated that performance and digestibility of nutrients in dairy cows can be sustained

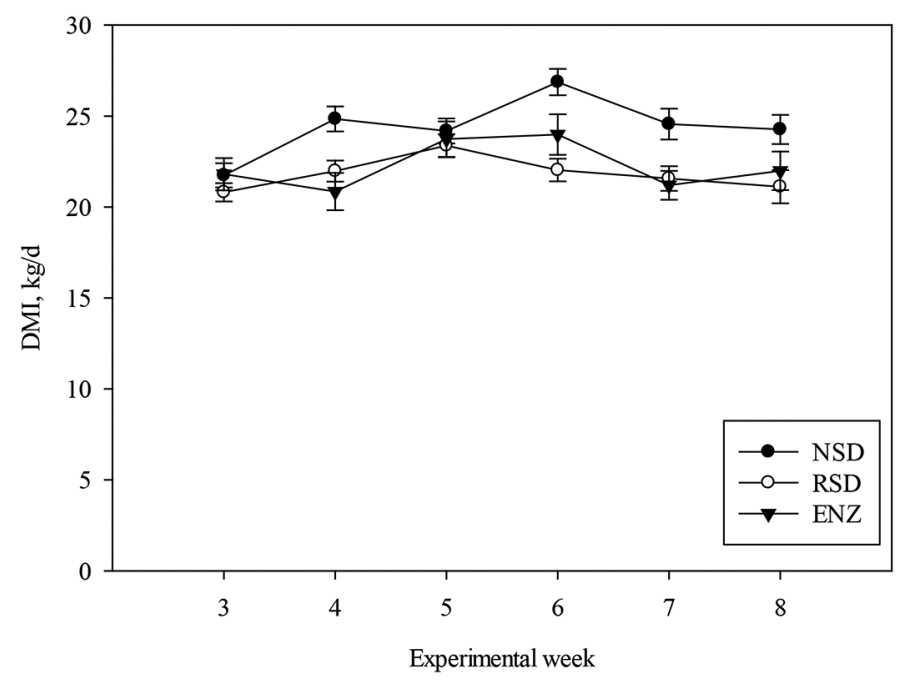

Figure 1. Dry matter intake of the cows during the experiment. Treatments were as follows: NSD = normal-starch diet (control); RSD $=$ reduced-starch diet; and ENZ $=$ RSD supplemented with Aspergillus spp. exogeneous enzyme product. Weeks 3 to 8 are experimental weeks during which data were collected for the statistical analysis (following a 2-wk covariate period and 2 wk for adaptation to treatments). Data are arithmetic means and associated SE; $n=18$ (number of independent observations used to derive each mean value). There was no effect $(P \geq 0.51)$ of treatment on DMI during wk 3 and 5 ; DMI was greater $(P \leq 0.03)$ for NSD vs. the reduced-starch diets during all other experimental weeks. when corn grain is replaced by brown midrib corn silage or nonforage fiber sources, the use of feed ingredients with more digestible NDF and other digestible nutrients was out of the scope of this study because the main idea was to challenge the capacity of the EEP to enhance availability of energy in RSD by replacing all the corn grain with a highly lignified NDF source (i.e., straw). Moreover, the use of other NDF sources would bring other digestible nutrients to the diet and be a confounding factor in the study. The beneficial effects of starch on overall rumen fermentation and microbial protein synthesis are well documented (Beckman and Weiss, 2005; Hristov et al., 2005; Salvati et al., 2021). Recent studies have demonstrated the possibility of maintaining cow performance even when lowering starch content in diets by replacing corn grain by nonforage fiber sources (e.g., beet pulp, wheat middlings; Dann et al., 2014, 2015) by increasing the amount of forage in the diet with the use of brown midrib silage hybrids (Ferraretto et al., 2015; Ferraretto and Shaver, 2015; Lim et al., 2015) or by supplementation of the diet with EEP (Arriola et al., 2017; Tirado-González et al., 2018). In the current study, however, milk production was decreased by RSD, primarily due to decreased DMI. Feed DMI is the dominant nutritional factor determining milk production in dairy cows (Hristov et al., 2004), and it was not surprising that the low DMI for RSD decreased MY, compared with NSD. The $18 \%$ higher NDF concentration of the RSD likely resulted in slower passage rate, which decreased DMI through rumen fill mechanisms (Dado and Allen, 1995; Allen, 2000; Miller et al., 2020).

Cows fed the reduced-starch diets had a 10\% increase in milk fat content, but milk fat yield did not differ from that of NSD. Many factors such as breed, stage of lactation, parity, diet formulation, and environment can influence milk composition (Jenkins and McGuire 2006). Increased milk fat content in response to feeding higher NDF concentration diets has been extensively reported in the literature (Varga et al., 1984; Beauchemin, 1991). Dann et al. (2015) reported a tendency for increased milk fat content when the concentrate feeds in a normal-starch diet were replaced by alfalfa, corn silage, and nonforage fiber sources. The increased milk fat content of cows fed the reduced-starch diets in the current study was likely a result of their greater concentration of physically effective fiber compared with NSD. Although particle size analysis of the diet was not performed in the current study, it is safe to assume that replacing (8-9\%) ground corn with chopped wheat straw would likely slightly increase overall TMR particle size for the reduced-starch diets. Mertens (1997) reported a positive relationship between physically effective fiber, milk fat content, and ruminal $\mathrm{pH}$ in 
Table 2. Dry matter intake, milk yield and composition, BW, and BCS of dairy cows fed normal- or reduced-starch diets without or with an exogenous enzyme product

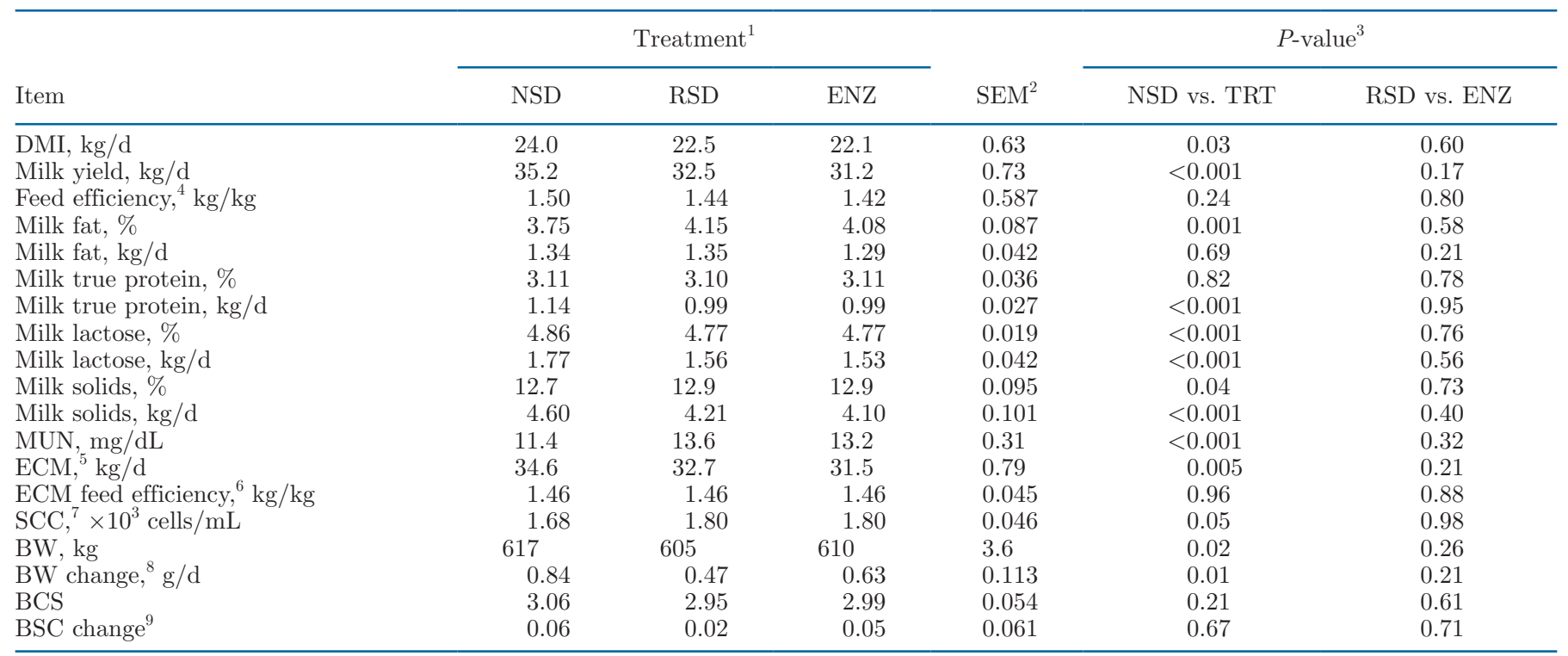

${ }^{1}$ Treatments were as follows: NSD = control; RSD = reduced-starch; ENZ = RSD supplemented with Aspergillus spp. exogenous enzyme product.

${ }^{2}$ Largest SEM published in table; $\mathrm{n}=279$ for all variables except DMI and milk yield, for which $\mathrm{n}=280$ (n represents number of observations used in the statistical analysis).

${ }^{3}$ Orthogonal contrasts: NSD vs. TRT $=$ NSD vs. RSD and ENZ; RSD vs. ENZ $=$ RSD vs. ENZ. There was experimental week $\times$ treatment interaction for DMI $(P<0.001)$, feed efficiency $(P<0.001)$, lactose and MUN concentrations $(P \leq 0.04)$, and ECM feed efficiency $(P=0.006)$; experimental week $\times$ treatment interactions for all other variables, $P \geq 0.10$

${ }^{4}$ Milk yield/DMI.

${ }^{5}$ Energy-corrected milk $(\mathrm{kg} / \mathrm{d})=\mathrm{kg}$ of milk $\times[(38.3 \times \%$ fat $\times 10+24.2 \times \%$ true protein $\times 10+16.54 \times \%$ lactose $\times 10+20.7) / 3,140]$ as per Sjaunja et al. (1990).

${ }^{6} \mathrm{ECM}$ yield/DMI.

${ }^{7}$ Statistical analysis was performed on log-transformed data.

${ }^{8} \mathrm{BW}$ change, $\mathrm{g} / \mathrm{d}=$ [average BW $(\mathrm{kg})$ during experimental wk 8 - average BW $(\mathrm{kg})$ during second week of covariate period]/days on study.

${ }^{9} \mathrm{BCS}$ change $=$ (BCS during experimental wk 8 - BCS during second week of covariate period).

dairy cows. Rumen acetate and butyrate are the major precursors supporting milk fat synthesis (Jenkins and McGuire 2006), and increasing dietary NDF:starch ratio tends to increase the molar proportion of acetate, butyrate, and the acetate:propionate ratio (Beckman and Weiss, 2005).

The reduced milk lactose content and yield in cows fed the reduced-starch diets may have resulted from decreased rumen propionate concentration, which has often been reported for low-starch, high-fiber diets (Beauchemin, 1991; Dann et al., 2015). Propionate is the main gluconeogenesis precursor in ruminants, and the mammary gland is one of the tissues that have an obligatory requirement for glucose for lactose synthesis (Aschenbach et al., 2010). Therefore, milk lactose content and yield may have been compromised in the reduced-starch diets in our study by decreased ruminal propionate availability, also supported by the lower blood glucose concentration $4 \mathrm{~h}$ after feeding in RSD versus NSD (see later discussion).
Lower starch intake is the likely explanation for the higher MUN concentration associated with the reduced-starch diets (Gencoglu et al., 2010; NRC, 2001) compared with NSD. Greater intake of NFC, such as sugars and starch, increases the energy availability in the rumen and decreases ruminal production and flux of ammonia to the blood stream (Broderick, 2003). Consequently, dietary nitrogen use efficiency for milk protein synthesis is usually enhanced and the MUN concentration is decreased, as demonstrated by Hristov et al. (2005). Thus, it is possible to infer that NSD provided a greater energy availability for the rumen microbes to utilize ammonia for microbial protein synthesis, resulting in lower MUN (Nousiainen et al., 2004) compared with the reduced-starch diets. Oh et al. (2019) reported that MUN did not differ among cows fed with a basal normal-starch diet supplemented or not with the EEP used in the current study. In addition, the use of EEP in the Oh et al. (2019) study did not affect ruminal ammonia concentration and urine 
$\mathrm{N}$ excretion, which agrees with data from the current study. Lower energy availability for microbial protein synthesis in the rumen can also be related to the lower milk protein yield in cows fed the reduced-starch diets. Microbial protein is the main source of MP for dairy cows and, consequently, the main source of AA supplied to the mammary gland for milk protein synthesis.

The performance variables evaluated in the current study were not affected by ENZ. Previous studies have also reported no effects of amylolytic and fibrolytic EEP on milk production or composition (Peters et al., 2015; Oh et al., 2019), and overall milk production responses to EEP have been inconsistent (Beauchemin and Holtshausen, 2011; McCarthy et al., 2013; Takiya et al., 2017).

\section{Total-Tract Digestibility}

Intake of NDF and ADF did not differ between NSD and the reduced-starch diets (Table 3 ) due to decreased DMI with the latter diets (during the digestibility data collection period). Also, there were no differences in $\mathrm{NDF}$ and ADF intake between RSD and ENZ. Intake of $\mathrm{CP}$ was higher $(P=0.007)$ for NSD compared with $\mathrm{RSD}$, as a result of higher DMI with the former diet and higher CP concentration of corn grain versus wheat straw. As expected, starch intake was lower $(P<0.001)$ for the reduced-starch diets compared with NSD. Totaltract digestibility of DM and $\mathrm{OM}$ were decreased $(P$ $\leq 0.003)$ for the reduced-starch diets. Digestibility of
NDF tended to increase $(P=0.09)$ for the reducedstarch diets compared with NSD and was not affected by ENZ. There were no differences in ADF and starch total-tract digestibility among treatments.

The decreased total-tract apparent DM and OM digestibility in cows fed the reduced-starch diets can be attributed to replacing NFC (from corn grain) by a fibrous carbohydrate source (from straw), resulting in an overall decrease in nutrient digestibility. The tendency for increased NDF digestibility in reduced-starch diets can be associated with increased retention time and lower passage rate of the digesta in cows fed a higher NDF diet (Dado and Allen, 1995). The differences between total-tract digestibility of NDF in NSD and reduced-starch diets can be partially explained by the difference in starch content of the diets. A negative relationship between NDF digestibility and dietary starch has been described in meta-analyses by Nousiainen et al. (2009) and Ferraretto et al. (2013). In these studies, ruminal and total-tract digestibility of NDF were decreased from 0.48 to 1.03 percentage units, respectively, per each unit of dietary starch increase. Although we did not find any effects of ENZ in nutrient digestibility, Gencoglu et al. (2010) reported increased digestibility of fiber fractions by an amylase EEP supplemented to a reduced-starch diet. In another study with lactating cows, Weiss et al. (2011) also reported enhanced NDF digestibility of a low-starch diet supplemented with an amylase EEP. It should be noted, however, that unlike the above studies, the EEP used in the current

Table 3. Nutrient intake and apparent total-tract digestibility of dairy cows fed normal- or reduced-starch diets without or with an exogenous enzyme product

\begin{tabular}{|c|c|c|c|c|c|c|}
\hline Item & \multicolumn{3}{|c|}{ Treatment $^{1}$} & $\mathrm{SEM}^{2}$ & \multicolumn{2}{|c|}{$P$-value ${ }^{3}$} \\
\hline \multicolumn{7}{|c|}{ Intake, ${ }^{4} \mathrm{~kg} / \mathrm{d}$} \\
\hline $\mathrm{OM}$ & 23.5 & 19.7 & 20.5 & 1.13 & 0.02 & 0.59 \\
\hline NDF & 8.32 & 8.24 & 8.59 & 0.444 & 0.85 & 0.55 \\
\hline $\mathrm{ADF}$ & 5.13 & 5.29 & 5.52 & 0.283 & 0.41 & 0.53 \\
\hline \multicolumn{7}{|c|}{ Apparent total-tract digestibility, $\%$} \\
\hline $\mathrm{DM}$ & 61.5 & 59.7 & 58.6 & 0.65 & $<0.001$ & 0.11 \\
\hline $\mathrm{OM}$ & 64.2 & 62.4 & 62.0 & 0.60 & 0.003 & 0.60 \\
\hline $\mathrm{NDF}$ & 34.7 & 38.2 & 37.0 & 1.38 & 0.09 & 0.54 \\
\hline $\mathrm{ADF}$ & 35.3 & 37.7 & 35.3 & 1.31 & 0.39 & 0.15 \\
\hline $\mathrm{CP}$ & 64.1 & 65.3 & 64.3 & 1.33 & 0.60 & 0.55 \\
\hline Starch & 96.7 & 96.6 & 96.4 & 0.20 & 0.49 & 0.33 \\
\hline
\end{tabular}

${ }^{1}$ Treatments were as follows: NSD = control; RSD = reduced-starch; ENZ = RSD supplemented with Aspergillus spp. exogenous enzyme product.

${ }^{2}$ Largest SEM published in table; $\mathrm{n}=47$ ( $\mathrm{n}$ represents number of observations used in the statistical analysis).

${ }^{3}$ Orthogonal contrasts: NSD vs. TRT $=$ NSD vs. RSD and ENZ; RSD vs. ENZ = RSD vs. ENZ.

${ }^{4}$ Intake during the digestibility data collection week (experimental wk 8). 
experiment contained both amylolytic and fibrolytic activities.

The modes of action of EEP differ among preparations and can be classified according to their site of activity, such as pre-consumptive, ruminal, or postruminal effects (McAllister et al., 2001). Past research suggests that Aspergillus oryzae-based EEP can increase ruminal bacteria counts (Newbold et al., 1992a,b) and can work synergistically with extracts from ruminal microorganisms, thus enhancing the nutrient release from plant cell walls in the rumen (Newbold, 1995). Furthermore, EEP use has been associated with an increase in total enzymatic activity in the rumen, which could increase the overall ruminal hydrolytic capacity, leading to enhanced digestibility of all dietary nutrients (Beauchemin et al., 2004).

Although we did not measure rumen fermentation variables in this study, the interpretation of the data allowed us to infer that replacing ground corn by wheat straw decreased energy availability to both the rumen microbes and the host animal, which led to decreased MY of cows fed the reduced-starch diets. Supporting current data, Oh et al. (2019) did not observe any differences in the total-tract digestibility of nutrients in cows fed ENZ supplemented to a normal-starch diet. As argued earlier, the variation in animal performance

Table 4. Blood plasma AA concentration $(\mu M)$ in dairy cows fed normal- or reduced-starch diets without or with an exogenous enzyme product

\begin{tabular}{|c|c|c|c|c|c|c|}
\hline \multirow[b]{2}{*}{ Item } & \multicolumn{3}{|c|}{ Treatment $^{1}$} & \multirow[b]{2}{*}{$\mathrm{SEM}^{2}$} & \multicolumn{2}{|c|}{$P$-value ${ }^{3}$} \\
\hline & NSD & RSD & ENZ & & NSD vs. TRT & RSD vs. ENZ \\
\hline His & 63.8 & 62.8 & 63.2 & 2.87 & 0.82 & 0.92 \\
\hline Ile & 183 & 180 & 178 & 9.9 & 0.67 & 0.86 \\
\hline Leu & 195 & 195 & 191 & 10.2 & 0.86 & 0.76 \\
\hline Lys & 104 & 104 & 103 & 5.4 & 0.97 & 0.96 \\
\hline Thr & 127 & 116 & 120 & 6.70 & 0.29 & 0.69 \\
\hline Trp & 63.7 & 64.4 & 62.3 & 2.70 & 0.92 & 0.60 \\
\hline Val & 366 & 366 & 352 & 19.2 & 0.77 & 0.59 \\
\hline$\Sigma \mathrm{EAA}^{4}$ & 1,279 & 1,272 & 1,244 & 56.1 & 0.74 & 0.71 \\
\hline Ala & 324 & 326 & 331 & 17.3 & 0.83 & 0.86 \\
\hline Asn & 52.1 & 49.7 & 48.6 & 2.72 & 0.39 & 0.76 \\
\hline Asp & 7.64 & 8.13 & 7.55 & 0.370 & 0.67 & 0.28 \\
\hline Orn & 59.5 & 63.8 & 60.8 & 3.30 & 0.49 & 0.53 \\
\hline Pro & 114 & 106 & 104 & 5.38 & 0.16 & 0.84 \\
\hline Ser & 98.2 & 90.4 & 88.1 & 4.14 & 0.10 & 0.70 \\
\hline Tau & 69.2 & 66.6 & 72.0 & 4.75 & 0.98 & 0.35 \\
\hline Tyr & 56.9 & 53.7 & 51.8 & 3.12 & 0.28 & 0.67 \\
\hline$\Sigma \mathrm{NEAA}^{5}$ & 1,537 & 1,490 & 1,509 & 56.7 & 0.59 & 0.80 \\
\hline Carnosine $^{6}$ & 11.1 & 11.1 & 12.2 & 1.31 & 0.74 & 0.49 \\
\hline $1-\mathrm{MH}^{7}$ & 22.6 & 24.1 & 23.5 & 1.58 & 0.48 & 0.75 \\
\hline $3-\mathrm{MH}^{7}$ & 4.60 & 4.13 & 5.93 & 0.535 & 0.52 & 0.02 \\
\hline$\alpha$-Aminoadipic acid & 15.5 & 15.7 & 18.0 & 1.29 & 0.33 & 0.13 \\
\hline$\alpha$-Aminobutyric acid & 17.1 & 18.3 & 17.6 & 1.14 & 0.52 & 0.65 \\
\hline$\beta$-Alanine & 1.84 & 1.76 & 1.85 & 0.143 & 0.80 & 0.63 \\
\hline Ethanolamine & 2.42 & 2.13 & 2.04 & 0.149 & 0.06 & 0.64 \\
\hline
\end{tabular}

${ }^{1}$ Treatments were as follows: NSD = control; RSD = reduced-starch; ENZ = RSD supplemented with Aspergillus spp. exogenous enzyme product.

${ }^{2}$ Largest SEM published in table; $\mathrm{n}=47$ ( $\mathrm{n}$ represents number of observations used in the statistical analysis).

${ }^{3}$ Orthogonal contrasts: NSD vs. TRT $=$ NSD vs. RSD and ENZ; RSD vs. ENZ $=$ RSD vs. ENZ.

${ }^{4}$ Sum of EAA (Arg, His, Ile, Leu, Lys, Phe, Thr, Trp, and Val).

${ }^{5}$ Sum of NEAA (Ala, Asn, Asp, Cys, Cit, Gln, Glu, Gly, Orn, Pro, Ser, Tau, and Tyr were considered as NEAA).

${ }^{6}$ Dipeptide ( $\beta$-alanyl-L-His).

${ }^{7}$ Methylhistidine.

${ }^{8} \gamma$-Aminobutyric acid. 
responses to EEP may be related to their properties, dose applied, and diet fed (Beauchemin et al., 2003; Meale et al., 2014). With the current heightened interest in direct-fed microbials, the dairy industry would benefit from future studies designed to evaluate how EEP products interact with dietary nutrients, feed ingredient composition, and different energy sources.

\section{Plasma AA Concentrations}

Concentrations of most plasma AA were not different across treatments (Table 4). Concentration of 3-methylhistidine $(\mathbf{3}-\mathbf{M H})$ was greater $(P=0.02)$ for ENZ compared with RSD. Concentration of ethanolamine tended to be greater $(P=0.06)$ for NSD versus the reduced-starch diets, and that of $\gamma$-aminobutyric acid (GABA) tended to be greater $(P=0.09)$ for the reduced-starch diets compared with NSD.

Greater plasma 3-MH concentration for ENZ suggested increased muscle catabolism (compared with RSD). It is well documented that methylation of histidine in actin and myosin results in the formation of $3-\mathrm{MH}$, and its occurrence in plasma (or urine) is an indication of protein mobilization in dairy cows (Harris and Milne, 1981; Houweling et al., 2012). The tendency for decreased ethanolamine in cows fed the reduced-starch diets also supported the hypothesis that replacing ground corn with wheat straw decreased availability of nutrients for the animals and resulted in an energy-deficient diet. Milk ethanolamine has a positive correlation $(\mathrm{r}=0.52)$ with the animal's energy balance (Xu et al., 2020), and its reduction, accompanied by 3 -MH increase, suggests that cows fed the reduced-starch diets tried to compensate the lower energy supply by mobilizing muscle tissue. Our study also corroborates with that of Saleem et al. (2012), who reported increased ethanolamine concentrations in the rumen fluid of cows fed a high-grain diet.

$\gamma$-Aminobutyric acid is a neurotransmitter that may regulate consumption through the inhibition of the vagus nerve. Therefore, higher GABA concentrations are expected to stimulate appetite (Forbes, 2007), and plasma concentration of GABA is reduced when the absorption of ruminal propionate is increased, triggering what is described as hepatic oxidation theory (Allen, 2000; Maldini and Allen, 2018). Our results demonstrated that GABA tended to increase in cows fed reduced-starch diets, which agreed with the lower DMI and possibly reduced output of propionate from the rumen.

\section{Blood Metabolites and Insulin}

Plasma total FA, BHB, BUN, and overall insulin concentrations did not differ among treatments (Table $5)$. The overall plasma glucose concentration tended to be lower $(P=0.06)$ in cows fed reduced-starch diets, compared with NSD, and glucose concentration at 4 $\mathrm{h}$ after feeding was decreased $(P<0.001)$ in cows fed the former diets. Cows fed ENZ had greater $(P=0.01)$ glucose and tended to have higher $(P=0.07)$ insulin concentration at $4 \mathrm{~h}$ after feeding when compared with cows fed RSD.

Circulating concentrations of total FA and BHB can be used as energy balance markers, with total FA being related to fat mobilization and BHB related to liver oxidation and ketone bodies formation (Duffield et al., 2009; Ospina et al., 2010). Holtshausen et al. (2011) and Dean et al. (2013) reported that cows receiving EEP had lower plasma BHB concentration compared with cows fed a control diet. To our knowledge, the present study was the first to report the effect of an EEP

Table 5. Blood plasma metabolites and insulin concentration in dairy cows fed a normal- or reduced-starch diets without or with an exogenous enzyme product

\begin{tabular}{|c|c|c|c|c|c|c|}
\hline \multirow[b]{2}{*}{ Item } & \multicolumn{3}{|c|}{ Treatment $^{1}$} & \multirow[b]{2}{*}{$\mathrm{SEM}^{2}$} & \multicolumn{2}{|c|}{$P$-value ${ }^{3}$} \\
\hline & NSD & RSD & ENZ & & NSD vs. TRT & RSD vs. ENZ \\
\hline $\mathrm{BHB}, \mu M$ & 1,027 & 1,086 & 932 & 90.6 & 0.86 & 0.18 \\
\hline $\mathrm{BUN}, \mathrm{mg} / \mathrm{dL}$ & 7.43 & 8.89 & 9.66 & 1.165 & 0.22 & 0.65 \\
\hline Glucose, $\mathrm{mg} / \mathrm{dL}$ & 82.2 & 72.2 & 77.8 & 3.02 & 0.06 & 0.19 \\
\hline Insulin, $\mu \mathrm{g} / \mathrm{L}$ & 1.22 & 1.23 & 0.96 & 0.134 & 0.46 & 0.15 \\
\hline
\end{tabular}

${ }^{1}$ Treatments were as follows: NSD = control; RSD = reduced-starch; ENZ = RSD supplemented with Aspergillus spp. exogenous enzyme product.

${ }^{2}$ Largest SEM published in table; $\mathrm{n}=47$ ( $\mathrm{n}$ represents number of observations used in the statistical analysis).

${ }^{3}$ Orthogonal contrasts: NSD vs. TRT $=$ NSD vs. RSD and ENZ; RSD vs. ENZ $=$ RSD vs. ENZ.

${ }^{4}$ Plasma glucose and insulin concentrations $4 \mathrm{~h}$ after feeding. 
containing both amylolytic and fibrolytic activities on energy metabolism markers in dairy cows. Although the tendency for reduction in plasma ethanolamine (e.g., energy balance marker) and the increase in 3-MH (e.g., muscle mobilization marker) concentrations suggest greater tissue mobilization, plasma concentrations of total FA and BHB, and BCS changes did not support the hypothesis that cows fed the decreased-starch diets mobilized more tissue in response to an energy-deficient diet in our study. It is noted, however, that cows fed the reduced-starch diets were clearly not gaining as much BW as cows fed NSD, which reflected the lower dietary energy supply by RSD versus NSD.
Blood glucose is extensively produced through hepatic gluconeogenesis, and its concentration is also an indicator of the energy metabolism status of the lactating dairy cow (Drackley and Cardoso, 2014). The mechanisms that led to decreased glucose concentration in cows fed the reduced-starch diets were discussed in the above section. Increased insulin concentration postfeeding is a response to increased intake of nutrients and is positively correlated with blood glucose concentration (Livingstone and Borai, 2014). Thus, the 4-h postfeeding glucose and insulin data for ENZ suggested improved energy availability compared with RSD, although the improvement was not large enough

Table 6. Fatty acid composition of milk fat (g/100 g of total fatty acids) in dairy cows fed normal- or reduced-starch diets without or with an exogenous enzyme product

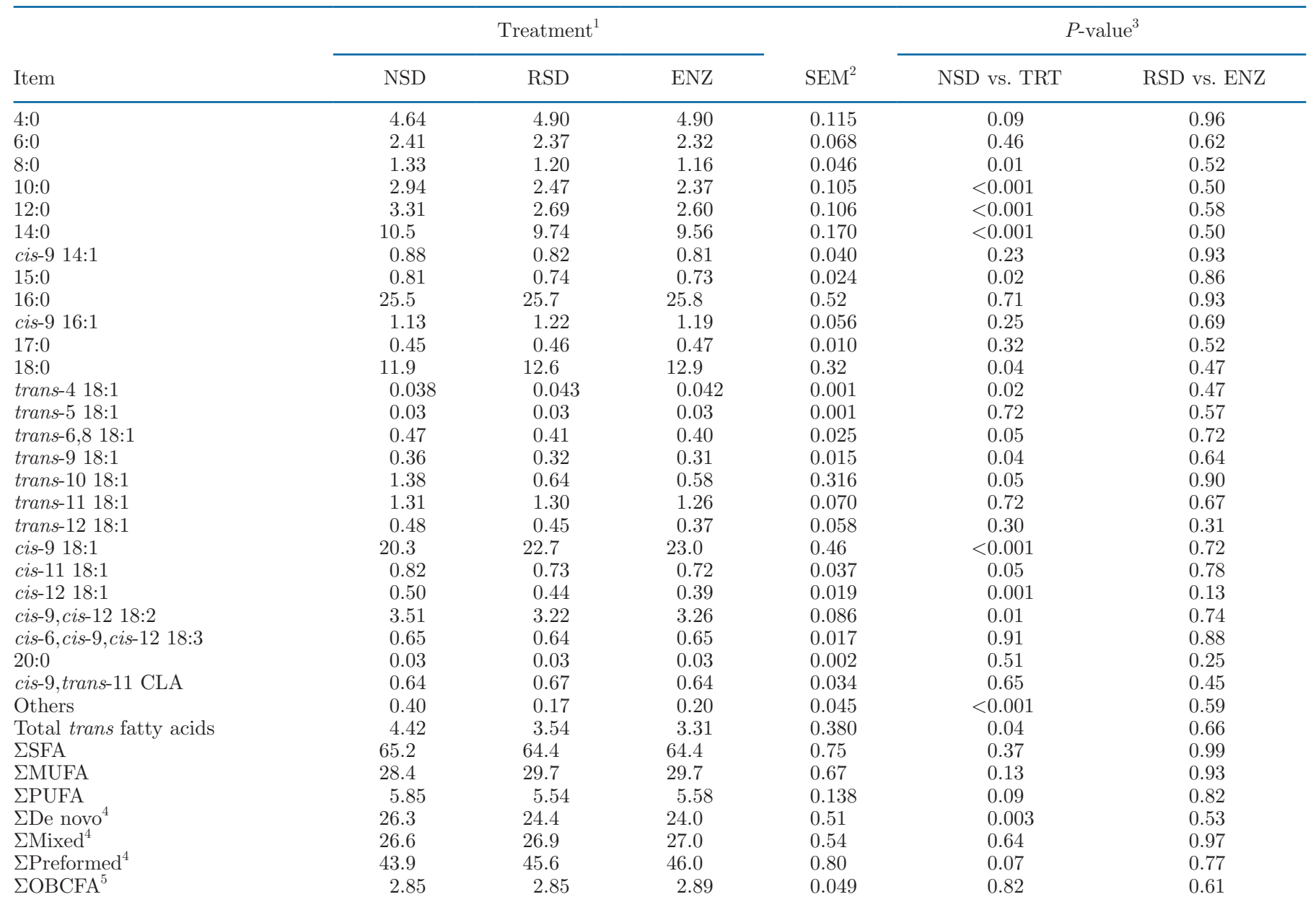

${ }^{1}$ Treatments were as follows: NSD = control; RSD = reduced-starch; ENZ = RSD supplemented with Aspergillus spp. exogenous enzyme product.

${ }^{2}$ Largest SEM published in table; $\mathrm{n}=47$ ( $\mathrm{n}$ represents number of observations used in the statistical analysis).

${ }^{3}$ Orthogonal contrasts: NSD vs. TRT $=$ NSD vs. RSD and ENZ; RSD vs. ENZ $=$ RSD vs. ENZ.

${ }^{4}$ De novo FA (C4:0 to C15:0) are synthesized by the mammary gland; preformed FA (C17:0 to C20:0) originate primarily from extraction from plasma; and mixed fatty acids (sum of iso C16:0, C16:0, and C16:1 cis-9) originate from both sources.

${ }^{5}$ Odd- and branched-chain FA (sum of $\mathrm{C} 11: 0$, iso C13:0, anteiso $\mathrm{C} 13: 0, \mathrm{C} 13: 0$, iso C14:0, iso C15:0, anteiso C15:0, C15:0, iso C16:0, iso C17:0, anteiso $\mathrm{C} 17: 0, \mathrm{C} 17: 0$, and $\mathrm{C} 17: 1$ cis-9). 
to result in an increased productive performance of the cows.

\section{Milk FA Composition}

Milk FA composition was only affected by dietary starch level (Table 6). Milk concentration of butyrate (4:0) tended to increase $(P=0.09)$, but concentrations of most de novo synthesized FA (8:0, 10:0, 12:0, and 14:0) and 15:0 were decreased $(P \leq 0.02)$ by the reduced-starch diets compared with NSD. Concentrations of 18:0, trans-4 18:1, and cis-9 18:1 were higher $(P \leq 0.04)$, and concentrations of preformed FA tended to be higher $(P \leq 0.07)$ in cows fed RSD when compared with cows fed NSD. Conversely, concentrations of trans-6,8 18:1, trans-9 18:1, trans-10 18:1, cis-11 18:1, cis-12 18:1, cis-9,cis-12 18:2, and the sums of total trans and de novo FA were all decreased $(P \leq 0.05)$ by the reduced-starch diets.

Milk fat depression is a syndrome generally characterized by a reduction in fat yield in response to altered rumen biohydrogenation when high-concentrate, low-forage diets or excessive dietary PUFA are fed to lactating cows (Bauman and Griinari, 2003). Studies report that cows experiencing biohydrogenation-induced milk fat depression have decreased concentrations of de novo FA and increased concentrations of trans-10 18:1 in milk (Shingfield et al., 2006; Gama et al., 2008; Rico and Harvatine, 2013). This, however, was not the case in the current study; cows fed the reduced-starch diets had lower concentration of trans-10 18:1, decreased concentration of de novo FA, and still had increased milk fat content, compared with NSD. It is possible that the lower fermentability of the reduced-starch diets affected the synthesis of de novo FA by reducing the availability of substrates in the mammary gland. Preformed FA in milk originate from the digestive tract or from adipose tissue mobilization (McGuire and Bauman, 2002; Harvatine et al., 2009), and the tendency for increased concentration of these FA in cows fed the reduced-starch diets was likely a consequence of increased body reserves mobilization (as a response to the lower energy balance, compared with NSD), which could help explain the difference in milk fat content between NSD and the reduced-starch diets.

\section{CONCLUSIONS}

A $26 \%$ reduction in dietary starch concentration (by substituting ground corn grain with wheat straw) decreased DMI and MY in mid-lactation dairy cows. Although both reduced-starch diets induced higher milk fat concentration, ECM yield was decreased by $7 \%$, compared with the control diet. Our hypothesis that an EEP containing amylolytic and fibrolytic activities would enhance structural carbohydrate degradation, and thus maintain the productivity of the cows, on a reduced-starch diet was not validated. The use of the enzyme additive increased postprandial blood glucose concentration, but this was not sufficient to compensate for the decreased dietary energy intake and to maintain production of the cows.

\section{ACKNOWLEDGMENTS}

This work was supported by the USDA (Washington, DC) National Institute of Food and Agriculture Federal Appropriations under project PEN 04539 and accession number 1000803. The authors thank Purina Animal Nutrition (Arden Hills, MN) for providing partial financial support and the ENZ supplement for this project. The authors also thank the staff of The Pennsylvania State University Dairy Teaching and Research Center (University Park) for their conscientious care and management of the experimental cows and for technical assistance during the study. The authors have not stated any conflicts of interest.

\section{REFERENCES}

Allen, M. S. 1996. Physical constraints on voluntary intake of forages by ruminants. J. Anim. Sci. 74:3063-3075. https://doi.org/10 $.2527 / 1996.74123063 x$.

Allen, M. S. 2000. Effects of diet on short-term regulation of feed intake by lactating dairy cattle. J. Dairy Sci. 83:1598-1624. https:// doi.org/10.3168/jds.S0022-0302(00)75030-2.

AOAC International. 2000. Official Methods of Analysis. 17th ed. AOAC International.

AOAC International. 2006. Official Methods of Analysis. 18th ed. AOAC International.

Arriola, K. G., S. C. Kim, C. R. Staples, and A. T. Adesogan. 2011. Effect of fibrolytic enzyme application to low- and high-concentrate diets on the performance of lactating dairy cattle. J. Dairy Sci. 94:832-841. https://doi.org/10.3168/jds.2010-3424.

Arriola, K. G., A. S. Oliveira, Z. X. Ma, I. J. Lean, M. C. Giurcanu, and A. T. Adesogan. 2017. A meta-analysis on the effect of dietary application of exogenous fibrolytic enzymes on the performance of dairy cows. J. Dairy Sci. 100:4513-4527. https://doi.org/10.3168/ jds.2016-12103.

Aschenbach, J. R., N. B. Kristensen, S. S. Donkin, H. M. Hammon, and G. B. Penner. 2010. Gluconeogenesis in dairy cows: The secret of making sweet milk from sour dough. IUBMB Life 62:869-877. https://doi.org/10.1002/iub.400.

Bauman, D. E., and J. M. Griinari. 2003. Nutritional regulation of milk fat synthesis. Annu. Rev. Nutr. 23:203-227. https://doi.org/ 10.1146/annurev.nutr.23.011702.073408.

Beauchemin, K., D. Colombatto, D. Morgavi, and W. Yang. 2003. Use of exogenous fibrolytic enzymes to improve feed utilization by ruminants. J. Anim. Sci. 81:E37-E47.

Beauchemin, K. A. 1991. Effects of dietary neutral detergent fiber concentration and alfalfa hay quality on chewing, rumen function, and milk production of dairy cows. J. Dairy Sci. 74:3140-3151. https:/ /doi.org/10.3168/jds.S0022-0302(91)78499-3.

Beauchemin, K. A., D. Colombatto, D. P. Morgavi, W. Z. Yang, and L. M. Rode. 2004. Mode of action of exogenous cell wall degrading enzymes for ruminants. Can. J. Anim. Sci. 84:13-22. https://doi .org/10.4141/A02-102. 
Beauchemin, K. A., and L. Holtshausen. 2011. Developments in enzyme usage in ruminants. Pages 206-230 in Enzymes in Farm Animal Nutrition. 2nd ed. M. R. Bedford and G. G. Partridge, ed. CAB International.

Beckman, J. L., and W. P. Weiss. 2005. Nutrient digestibility of diets with different fiber to starch ratios when fed to lactating dairy cows. J. Dairy Sci. 88:1015-1023. https://doi.org/10.3168/jds .S0022-0302(05)72769-7.

Broderick, G. A. 2003. Effects of varying dietary protein and energy levels on the production of lactating dairy cows. J. Dairy Sci. 86:1370-1381. https://doi.org/10.3168/jds.S0022-0302(03)73721 $-7$.

Dado, R. G., and M. S. Allen. 1995. Intake limitations, feeding behavior, and rumen function of cows challenged with rumen fill from dietary fiber or inert bulk. J. Dairy Sci. 78:118-133. https://doi .org/10.3168/jds.S0022-0302(95)76622-X.

Dann, H. M., S. M. Fredin, K. W. Cotanch, R. J. Grant, C. Kokko, P. Ji, and K. Fujita. 2015. Effects of corn-based reduced-starch diets using alternative carbohydrate sources on performance of lactating Holstein cows. J. Dairy Sci. 98:4041-4054. https://doi.org/10 $.3168 /$ jds.2014-9078.

Dann, H. M., H. A. Tucker, K. W. Cotanch, P. D. Krawczel, C. S. Mooney, R. J. Grant, and T. Eguchi. 2014. Evaluation of lower-starch diets for lactating Holstein dairy cows. J. Dairy Sci. 97:7151-7161. https://doi.org/10.3168/jds.2014-8341.

Dean, D. B., C. R. Staples, R. C. Littell, S. Kim, and A. T. Adesogan. 2013. Effect of method of adding a fibrolytic enzyme to dairy cow diets on feed intake digestibility, milk production, ruminal fermentation, and blood metabolites. Anim. Nutr. Feed Technol. 13:337-353.

Deyl, Z., J. Hyanek, and M. Horakova. 1986. Profiling of amino acids in body fluids and tissues by means of liquid chromatography. J. Chromatogr. 379:177-250. https://doi.org/10.1016/S0378 $-4347(00) 80685-4$.

Drackley, J. K., and F. C. Cardoso. 2014. Prepartum and postpartum nutritional management to optimize fertility in high-yielding dairy cows in confined TMR systems. Animal 8:5-14. https://doi.org/10 $.1017 /$ S1751731114000731.

Duffield, T. F., K. D. Lissemore, B. W. McBride, and K. E. Leslie. 2009. Impact of hyperketonemia in early lactation dairy cows on health and production. J. Dairy Sci. 92:571-580. https://doi.org/ $10.3168 /$ jds.2008-1507.

Fekkes, D. 1996. State-of-the-art of high-performance liquid chromatographic analysis of amino acids in physiological samples. J. Chromatogr. B. Biomed. Appl. 682:3-22. https://doi.org/10.1016/0378 $-4347(96) 00057-6$.

Ferraretto, L. F., P. M. Crump, and R. D. Shaver. 2013. Effect of cereal grain type and corn grain harvesting and processing methods on intake, digestion, and milk production by dairy cows through a meta-analysis. J. Dairy Sci. 96:533-550. https://doi.org/10.3168/ jds.2012-5932.

Ferraretto, L. F., P. M. Crump, and R. D. Shaver. 2015. Effect of ensiling time and exogenous protease addition to whole- plant corn silage of various hybrids, maturities, and chop lengths on nitrogen fractions and ruminal in vitro starch digestibility. J. Dairy Sci. 98:8869-8881. https://doi.org/10.3168/jds.2015-9511.

Ferraretto, L. F., and R. D. Shaver. 2015. Effects of whole-plant corn silage hybrid type on intake, digestion, ruminal fermentation, and lactation performance by dairy cows through a meta-analysis. J. Dairy Sci. 98:2662-2675. https://doi.org/10.3168/jds.2014-9045.

Forbes, J. M. 2007. Voluntary food intake and diet selection in farm animals. 2nd ed. CABI.

Gama, M. A. S., P. C. Garnsworthy, J. M. Griinari, P. R. Leme, P. H. M. Rodrigues, L. W. O. Souza, and D. P. D. Lanna. 2008. Dietinduced milk fat depression: Association with changes in milk fatty acid composition and fluidity of milk fat. Livest. Sci. 115:319-331. https://doi.org/10.1016/j.livsci.2007.08.006.

Gencoglu, H., R. D. Shaver, W. Steinberg, J. Ensink, L. F. Ferraretto, S. J. Bertics, J. C. Lopes, and M. S. Akins. 2010. Effect of feeding a reduced-starch diet with or without amylase addition on lacta- tion performance in dairy cows. J. Dairy Sci. 93:723-732. https:// doi.org/10.3168/jds.2009-2673.

Hall, M. B. 2009. Determination of starch, including maltooligosaccharides, in animal feeds: Comparison of methods and a method recommended for AOAC collaborative study. J. AOAC Int. 92:42-49. https://doi.org/10.1093/jaoac/92.1.42.

Harris, C. I., and G. Milne. 1981. The urinary excretion of N-taumethyl histidine by cattle: Validation as an index of muscle protein breakdown. Br. J. Nutr. 45:411-422. https://doi.org/10.1079/ BJN19810116.

Harvatine, K. J., Y. R. Boisclair, and D. E. Bauman. 2009. Recent advances in the regulation of milk fat synthesis. Animal 3:40-54. https://doi.org/10.1017/S1751731108003133.

Holtshausen, L., Y.-H. Chung, H. Gerardo-Cuervo, M. Oba, and K. A. Beauchemin. 2011. Improved milk production efficiency in early lactation dairy cattle with dietary addition of a developmental fibrolytic enzyme additive. J. Dairy Sci. 94:899-907. https://doi .org/10.3168/jds.2010-3573.

Houweling, M., S. G. A. van der Drift, R. Jorritsma, and A. G. M. Tielens. 2012. Technical note: Quantification of plasma 1- and 3-methylhistidine in dairy cows by high-performance liquid chromatography-tandem mass spectrometry. J. Dairy Sci. 95:31253130. https://doi.org/10.3168/jds.2011-4769.

Hristov, A. N., W. J. Price, and B. Shafii. 2004. A meta-analysis examining the relationship among dietary factors, dry matter intake, and milk yield and milk protein yield in dairy cows. J. Dairy Sci. 87:2184-2196. https://doi.org/10.3168/jds.S0022-0302(04)70039 $-9$.

Hristov, A. N., J. K. Ropp, K. L. Grandeen, S. Abedi, R. P. Etter, A. Melgar, and A. E. Foley. 2005. Effect of carbohydrate source on ammonia utilization in lactating dairy cows. J. Anim. Sci. 83:408421. https://doi.org/10.2527/2005.832408x.

Huhtanen, P., K. Kaustell, and S. Jaakkola. 1994. The use of internal markers to predict total digestibility and duodenal flow of nutrients in cattle given six different diets. Anim. Feed Sci. Technol. 48:211-227. https://doi.org/10.1016/0377-8401(94)90173-2.

Jenkins, T. C., and M. A. McGuire. 2006. Major advances in nutrition: Impact on milk composition. J. Dairy Sci. 89:1302-1310. https:// doi.org/10.3168/jds.S0022-0302(06)72198-1.

Lee, C., A. N. Hristov, T. W. Cassidy, K. S. Heyler, H. Lapierre, G. A. Varga, M. J. De Veth, R. A. Patton, and C. Parys. 2012. Rumenprotected lysine, methionine, and histidine increase milk protein yield in dairy cows fed a metabolizable protein-deficient diet. J. Dairy Sci. 95:6042-6056. https://doi.org/10.3168/jds.2012-5581.

Lim, J. M., K. E. Nestor Jr., and L. Kung Jr.. 2015. The effect of hybrid type and dietary proportions of corn silage on the lactation performance of high-producing dairy cows. J. Dairy Sci. 98:11951203. https://doi.org/10.3168/jds.2014-8725.

Livingstone, C., and A. Borai. 2014. Insulin-like growth factor-II: Its role in metabolic and endocrine disease. Clin. Endocrinol. (Oxf.) 80:773-781. https://doi.org/10.1111/cen.12446.

Maldini, G., and M. S. Allen. 2018. Temporal effects of ruminal propionic acid infusion on feeding behavior of Holstein cows in the postpartum period. J. Dairy Sci. 101:3077-3084. https://doi.org/ $10.3168 /$ jds.2017-13857.

McAllister, T. A., A. N. Hristov, K. A. Beauchemin, L. M. Rode, and K. J. Cheng. 2001. Enzymes in ruminants diets. Pages 273-289 in Enzymes in Farm Animal Nutrition. M. R. Bedford and G. G. Partridge, ed. CABI Publishing.

McCarthy, M. M., M. A. Engstrom, E. Azem, and T. F. Gressley. 2013. The effect of an exogenous amylase on performance and total-tract digestibility in lactating dairy cows fed a high-byproduct diet. J. Dairy Sci. 96:3075-3084. https://doi.org/10.3168/jds.2012-6045.

McGuire, J. G., and D. E. Bauman. 2002. Milk biosynthesis and secretion. Pages 1828-1834 in Encyclopedia of dairy science. H. Roginski, J. W. Fuquay, and P. F. Fox, ed. Elsevier Science Ltd.

Meale, S. J., K. A. Beauchemin, A. N. Hristov, A. V. Chaves, and T. A. McAllister. 2014. Board-invited review: Opportunities and challenges in using exogenous enzymes to improve ruminant production. J. Anim. Sci. 92:427-442. https://doi.org/10.2527/jas.2013 -6869 . 
Mertens, D. R. 1994. Regulation of forage intake. Pages 450-493 in Forage Quality, Evaluation, and Utilization. G.C. Fahey Jr., ed. American Society of Agronomy Inc., Crop Science Society of America Inc., Soil Science Society of America Inc.

Mertens, D. R. 1997. Creating a system for meeting the fiber requirements of dairy cows. J. Dairy Sci. 80:1463-1481. https://doi.org/ 10.3168/jds.S0022-0302(97)76075-2.

Miller, M. D., J. S. Lanier, S. K. Kvidera, H. M. Dann, C. S. Ballard, and R. J. Grant. 2020. Evaluation of source of corn silage and trace minerals on rumen characteristics and passage rate of Holstein cows. J. Dairy Sci. 103:8864-8879. https://doi.org/10.3168/ jds.2020-18490.

Moe, P. W., W. P. Flatt, and H. F. Tyrell. 1972. Net energy value of feeds for lactation. J. Dairy Sci. 55:945-958. https://doi.org/10 $.3168 /$ jds.S0022-0302(72)85601-7.

Newbold, C. J. 1995. Microbial feed additives for ruminants. Pages 17-31 in Biotechnology in Animal Feeds and Animal Feeding. R. J. Wallace and H. C. Chesson ed. VCH Publishers Inc.

Newbold, C. J., R. Brock, and R. J. Wallace. 1992a. The effect of Aspergillus oryzae fermentation extract on the growth of fungi and ciliate protozoa in rumen. Lett. Appl. Microbiol. 15:109-112. https://doi.org/10.1111/j.1472-765X.1992.tb00739.x.

Newbold, C. J., P. P. Frumholtz, and R. J. Wallace. 1992b. Influence of Aspergillus oryzae fermentation extract on rumen fermentation and blood constituents in sheep given diets of grass hay and barley. J. Agric. Sci. 119:423-427. https://doi.org/10.1017/ S0021859600012272.

Nousiainen, J., M. Rinne, and P. Huhtanen. 2009. A meta-analysis of feed digestion in dairy cows. 1 . The effects of forage and concentrate factors on total digestibility. J. Dairy Sci. 92:5019-5030. https://doi.org/10.3168/jds.2008-1833.

Nousiainen, J., K. J. Shingfield, and P. Huhtanen. 2004. Evaluation of milk urea nitrogen as a diagnostic of protein feeding. J. Dairy Sci. 87:386-398. https://doi.org/10.3168/jds.S0022-0302(04)73178-1.

NRC. 2001. Nutrient Requirements of Dairy Cattle. 7th ed. National Academy Press.

Oba, M., and M. S. Allen. 1999. Evaluation of the importance of the digestibility of neutral detergent fiber from forage: Effects on dry matter intake and milk yield of dairy cows. J. Dairy Sci. 82:589596. https://doi.org/10.3168/jds.S0022-0302(99)75271-9.

Oh, J., M. Harper, A. Melgar, D. M. Paulus Compart, and A. N. Hristov. 2019. Effects of Saccharomyces cerevisiae-based directfed microbial and exogenous enzyme products on enteric methane emission and productivity in lactating dairy cows. J. Dairy Sci. 102:6065-6075. https://doi.org/10.3168/jds.2018-15753.

Ospina, P. A., D. V. Nydam, T. Stokol, and T. R. Overton. 2010. Associations of elevated nonesterified fatty acids and $\beta$-hydroxybutyrate concentrations with early lactation reproductive performance and milk production in transition dairy cattle in the northeastern United States. J. Dairy Sci. 93:1596-1603. https://doi.org/10.3168/jds .2009-2852.

Peters, A., U. Meyer, and S. Dänicke. 2015. Effect of exogenous fibrolytic enzymes on performance and blood profile in early and midlactation Holstein cows. Anim. Nutr. 1:229-238. https://doi.org/ 10.1016/j.aninu.2015.09.001.

Rico, D. E., and K. J. Harvatine. 2013. Induction of and recovery from milk fat depression occurs progressively in dairy cows switched between diets that differ in fiber and oil concentration. J. Dairy Sci. 96:6621-6630. https://doi.org/10.3168/jds.2013-6820.

Saleem, F., B. N. Ametaj, S. Bouatra, R. Mandal, Q. Zebeli, S. M. Dunn, and D. S. Wishart. 2012. A metabolomics approach to uncover the effects of grain diets on rumen health in dairy cows. J. Dairy Sci. 95:6606-6623. https://doi.org/10.3168/jds.2012-5403.
Salvati, G. G. S., W. P. Santos, J. M. Silveira, V. C. Gritti, B. A. V. Arthur, P. A. R. Salvo, L. Fachin, A. P. Ribeiro, N. N. Morais Júnior, L. F. Ferraretto, J. L. P. Daniel, K. A. Beauchemin, F. A. P. Santos, and L. G. Nussio. 2021. Effect of kernel processing and particle size of whole-plant corn silage with vitreous endosperm on dairy cow performance. J. Dairy Sci. 104:1794-1810. https://doi .org/10.3168/jds.2020-19428.

Schneider, B. H., and W. P. Flatt. 1975. The Evaluation of Feeds Through Digestibility Experiments. University of Georgia Press.

Shingfield, K. J., C. K. Reynolds, G. Hervas, J. M. Griinari, A. S. Grandison, and D. E. Beever. 2006. Examination of the persistency of milk fatty acid composition responses to fish oil and sunflower oil in the diet of dairy cows. J. Dairy Sci. 89:714-732. https: //doi.org/10.3168/jds.S0022-0302(06)72134-8.

Sjaunja, L. O., L. Baevre, L. Junkkarinen, J. Pedersen, and J. Setälä. 1990. A Nordic proposal for an energy corrected milk (ECM) formula. Pages 156-157 in 27th Session of the International Commission for Breeding and Productivity of Milk Animals. Wageningen Academic Publishers.

Takiya, C. S., G. D. Calomeni, T. H. Silva, T. H. A. Vendramini, G. G. Silva, C. E. C. Consentini, J. C. Bertoni, E. M. C. Zilio, and F. P. Rennó. 2017. Increasing dietary doses of an Aspergillus oryzae extract with alpha-amylase activity in nutrient digestibility and ruminal fermentation of lactating dairy cows. Anim. Feed Sci. Technol. 228:159-167. https://doi.org/10.1016/j.anifeedsci.2017 .04 .017 .

Tirado-González, D. N., L. A. Miranda-Romero, A. Ruíz-Flores, S. E. Medina-Cuéllar, R. Ramírez-Valverde, and G. Tirado-Estrada. 2018. Meta-analysis: Effects of exogenous fibrolytic enzymes in ruminant diets. J. Appl. Anim. Res. 46:771-783. https://doi.org/ 10.1080/09712119.2017.1399135.

USDA-ERS (Economic Research Service). 2021 Farm Sector Income Forecast. Accessed Apr. 3, 2021. https://www.ers.usda.gov/ topics/farm-economy/farm-sector-income-finances/farm-sector -income-forecast/

Van Soest, P. J., J. B. Robertson, and B. A. Lewis. 1991. Methods for dietary fiber, neutral detergent fiber, and nonstarch polysaccharides in relation to animal nutrition. J. Dairy Sci. 74:3583-3597. https://doi.org/10.3168/jds.S0022-0302(91)78551-2.

Varga, G. A., E. M. Meisterling, R. A. Dailey, and W. H. Hoover. 1984. Effect of low and high fill diets on dry matter intake, milk production, and reproductive performance during early lactation. J. Dairy Sci. 67:1240-1248. https://doi.org/10.3168/jds.S0022 $-0302(84) 81430-7$

Weiss, W. P., and J. M. Pinos-Rodriguez. 2009. Production responses by dairy cows when fed supplemental fat in low and high forage diets. J. Dairy Sci. 92:6144-6155. https://doi.org/10.3168/jds .2009-2558.

Weiss, W. P., W. Steinberg, and M. A. Engstrom. 2011. Milk production and nutrient digestibility by dairy cows when fed exogenous amylase with coarsely ground dry corn. J. Dairy Sci. 94:2492-2499. https://doi.org/10.3168/jds.2010-3766.

$\mathrm{Xu}$, W., J. V. Vervoort, E. Saccenti, B. Kemp, R. J. van Hoeij, and A. T. M. Knegsel. 2020. Relationship between energy balance and metabolic profiles in plasma and milk of dairy cows in early lactation. J. Dairy Sci. 103:4795-4805. https://doi.org/10.3168/jds 2019-17777.

Yang, Y., G. Ferreira, B. A. Corl, and B. T. Campbell. 2019. Production performance, nutrient digestibility, and milk fatty acid profile of lactating dairy cows fed corn silage- or sorghum silage-based diets with and without xylanase supplementation. J. Dairy Sci 102:2266-2274. https://doi.org/10.3168/jds.2018-15801. 